\title{
Yield and Weed Dynamics as Influenced by Different Rice Establishment Methods under Partial Irrigated Condition
}

\author{
Khilendra Kumar Sahu ${ }^{1 *}$, M. Kumar ${ }^{1}$, A. Pradhan $^{1}$, T. Chandrakar ${ }^{2}$ and D. P. Singh ${ }^{3}$ \\ ${ }^{1}$ Department of Agronomy, ${ }^{2}$ Department of soil science \& Agricultural Chemistry, \\ ${ }^{3}$ Department of Agricultural Statistics \& Social Science, S. G. College of Agriculture \& \\ Research Station, IGKV, Jagdalpur (C.G.), India \\ *Corresponding author
}

\section{A B S T R A C T}

\section{Keywords}

Rice, Crop establishment methods, Weed management, Kharif, Grain and Straw yield

\section{Article Info}

Accepted: 18 December 2020 Available Online: 10 January 2021
A field experiment was conducted on "Yield and weed dynamics as influenced by different rice establishment methods under partial irrigated condition" at Instructional cum research farm, S.G. College of Agriculture and Research Station, Jagdalpur, Chhattisgarh, India during Kharif 2019 in Split Plot Design (SPT) with treatments Main plot (3) and Subplot (4) with three replications. Transplanting\& sowing of Durgeshwari variety of rice was carried out on $1^{\text {st }}$ July 2019 maintaining crop geometry of $20 \times 10 \mathrm{~cm}$ within each plot and rice was harvested on $18^{\text {th }}$ November 2019 . The result showed that maximum plant height, tillers number per hill, number of leaves per plant, leaf area index, relative growth rate $\mathrm{N}$, $\mathrm{P}$ and $\mathrm{K}$ nutrient uptake in grain and straw, panicle $\mathrm{m}^{-2}$, panicle length, seeds per panicle and weight of 1000 seeds were obtained with transplanting method of establishment throughout the observations which was found significant and comparable to puddled direct seeding by drum seeder and weed control for above cited results were found with weed free treatment and comparable to chemical weeding The highest grain $\left(62.43 \mathrm{q} \mathrm{ha} \mathrm{h}^{-1}\right)$ and straw yield $\left(79.03 \mathrm{q} \mathrm{ha}^{-1}\right)$ of rice were noticed under treatment transplanting method of establishment and comparable with treatment puddled direct seeding by drum seeder. The lowest grain and straw yield (50.19 and $\left.70.01 \mathrm{q} \mathrm{ha}^{-1}\right)$ was recorded by unpuddled dry direct seeding by line sowing.

\section{Introduction}

(Rice (Oryza sativa L.), a member of the poaceae family, is one of the most essential food crops and constitutes the staple diet of 2.7 billion people. Almost 90 percent of the area and production of world rice produced and consumed in Asia and cultivated in all regions except Antarctica). Rice (Oryza sativa
L.) is an important food for more than half of the global population is known as "Global Grain" in 89 nations. The slogan "Rice is life" can be best fitted expression to our nation as this crop plays a vital role in our national food security. Among the rice growing countries, India has the largest area and it is the second largest producer of rice next to China (205.21 million tonnes). In India, rice is grown in 
43.86 million ha, the production level is 104.80 million tones and the productivity is about $2390 \mathrm{~kg} / \mathrm{ha}$. To meet the needs of the ever-growing population, India has to produce about 130 million tonnes of rice by 2025 (Hugar et al., 2009). There are 3 main methods of rice sowing; dry sowing (sowing dry seeds in dry soil), wet sowing (sowing pre-germinated seeds in moist puddle bottoms) and water sowing (sowing seeds in stagnant water).Dry direct sowing is done, respectively broadcast and row sowing with either a drum seeder under unpuddled fields. Sowing makes it easy to maintain row-to-row spacing, and losing seeds into hills is a powerful way of sowing rice in time, in addition to reducing exertions prices. Dry direct seeding of rice lets in early established order of the succeeding crop and higher income in regions with confident water deliver by using making use of brief duration present day types and cost efficient herbicides. So, there may be want to search for appropriate crop establishment techniques to boom the productivity and profitability of rice as reported by Farooq and co-worker (2011).

Transplanting is the most prevailing and conventional technique for establishment in irrigated lowland rice. The region under transplanted rice in world is diminishing because of shortage of water and labour. Hence, there is necessity to look for alternate method of crop establishment to increase the productivity of rice.

Direct seeding produces similar grain yield as that of transplanted rice although it diminishes labour requirement and shortens the crop duration by 7-10 days. Direct seeding retains $29 \%$ of the total cost and needs just $34 \%$ of the total labour requirement of transplanted rice (Ho and Romil, 2000).Chhattisgarh is a major rice growing state in our country known for a variety of cultivation practices with different genotypes. The state is recognized with the name "Rice Bowl of India". Northern Hills, Chhattisgarh plains and Bastar plateau are the three agroclimatic zones of the state catering practices of rice cultivation.

The area under rice cultivation is about 3.71 million hectares in around 37.10 lakh hectares with a total production of 7.29 million tonnes and $1.96 \mathrm{t} \mathrm{ha}^{-1}$ of productivity (Anonymous, 2019). The average area under summer rice cultivation is about 116.47 thousand hectare with an average production of 227.04 thousand tonnes. Chhattisgarh plains has the highest average area under summer and Kharif rice cultivation with 112.69 thousand hectares followed by northern hills with 3.13 thousand hectare.

Weeds are a serious trouble in direct sowing and compete for resources together with daylight, water and nutrient for growing. Therefore the mutual availability of units is confined competition is natural in tropical climates there may be an honest growth in weeds that become a major problem of crop growing in upland, no-until conditions, Inadequate crop spacing and fertility of land situations, additionally promotes weeds boom. An estimate indicates that weeds can deprive the crop of $47 \% \mathrm{~N}, 42 \% \mathrm{P}, 50 \% \mathrm{~K}, 39$ and $24 \% \mathrm{Mg}$ in their nutrient uptake, as well as lowering the capacity yield through housing some of plant pests confined by Balasubramaniyan and Palaniappan (2001) and that reported the change in crop cultivation technology from transplanted to wet rice cultivation has led to dramatic changes in the type and degree of weed infestation.Hence, present investigation entitled "Yield and weed dynamics as influenced by different rice establishment methods under partial irrigated condition" was conducted.. 


\section{Materials and Methods}

A field experiment was carried out during kharif season 2019 at Instructional cum Research Farm, S.G. College of Agriculture and Research Station, Kumhrawand, Jagdalpur, Chhattisgarh, India. The state Chhattisgarh is located between $17^{0} 30^{\prime}$ ' and $24^{\circ} 45^{\prime} \mathrm{N}$ latitude and $70^{\circ} 30^{\prime}$ and $84^{\circ} 15^{\prime} \mathrm{E}$ longitude whereas Bastar lies at $19^{0} 10^{\prime} \mathrm{N}$ latitude and $81^{\circ} 95^{\prime} \mathrm{E}$ longitude with an altitude of 553 meters above mean sea level. Climatologically, Jagdalpur comes under the seventh agro climatic region of India i.e. Eastern plateau and hills which is classified as subtropical humid with hot summer and cold winter. The source of rainfall is south western monsoon. It receives an average annual rainfall of $1416 \mathrm{~mm}$, mostly $(85 \%)$ precipitated during the period of June to September sometime in October also. A few showers are expected during winter and occasionally during summer months. The rainfall and temperature of the area is about $2313 \mathrm{~mm}$ and $31.6^{\circ} \mathrm{C}$ respectively during 2019 were recorded via meteorological observatory of S.G. CARS, IGKV, Jagdalpur. The crop encountered $2162.5 \mathrm{~mm}$ rainfall throughout its growth period and maximum temperature $30.1{ }^{\circ} \mathrm{C}$ to $34.8{ }^{\circ} \mathrm{C}$ of the experiment was allocated in split plot design with three replications on Inceptisol. The treatments comprised of Main plot treatment $\mathrm{CM}_{1}$ : Transplanting, $\mathrm{CM}_{2}$ : Puddled direct drum seeding, $\mathrm{CM}_{3}$ :unpuddled dry direct seeding by line sowing and subplot treatment $\mathrm{WM}_{1}$ : weed free, $\mathrm{WM}_{2}$ : weedy check and $\mathrm{WM}_{3}$ : mechanical weeding by conoweeder and $\mathrm{WM}_{4}$ : chemical weeding. The cultivar tested for the experiment was Durgeshwari having 130 days maturity with grains long slender and white with semi-dwarf $(111 \mathrm{~cm})$ stature, suitable for irrigated mid lands. As per the treatment, experimental plots were prepared and the nursery was transplanted in rows of spacing $20 \mathrm{~cm}$ and plant to plant spacing was about $10 \mathrm{~cm}$ on $22^{\text {th }}$ July 2019 after the land preparation and incorporation of a basal dose of fertilizer were done in the plots simultaneously. A fertilizer dose of 100:60:40 N: P: K Kg ha ${ }^{-1}$ was applied to the rice field. Basal application of fertilizers was done@100\% recommended dose of phosphorus and potassium during transplanting as well as at direct seeding of normal seeds and the sprouted seeds and remaining $50 \%$ nitrogen at 30 days after establishment.

\section{Results and Discussion}

\section{Growth parameters}

The data in respect to plant height are presented in Table 1.The plant height increased with the advancement of crop up to harvest stage in all the treatments. The significantly taller plant, number of tillers hill $^{-1}$, number of leavesplant ${ }^{-1}$, was observed under treatment transplanting method of establishment $\left(\mathrm{CM}_{1}\right)$ at all the crop growth stages. Further, the lowest growth characters were recorded under unpuddled dry direct seeding $\left(\mathrm{CM}_{3}\right)$ at all crop growth stages. However, in case of different weed management practices treatment weed free $\left(\mathrm{WM}_{1}\right)$ recorded significantly higher crop growth characters at all the crop growth stages.This result confirms with the findings of Aslam et al., (2008). Number of tillers production per plant depends on the proper sunlight and space provided to the plant during its growth, spaced plant received proper growth resources reflected on growth parameters and those conditions were fulfilled by transplanting method of rice appropriately. The result obtained was similar with the work of Ali et al., (2013). Singh et al., (1997) also confirmed higher plant height recorded in transplanted rice could be attributed to better nutrient uptake in competition free environment. While, tiller production starts 
slowly within the beginning, will increase secure and attains to its greatest throughout raceme initiation stage so began to decline because the age of the crop improvements. The decrease in tiller variety on aging resulted from death of the late forming tillers thanks to their inability for lightweight and nutrients (Barik et al., 2006).

Leaf Area Index (LAI) is a measurement of land covered via growing biomass on surface directly proportionate to the production of crop in terms of yield (Table1). The significantly highest leaf area index was observed under treatment transplanting method of establishment $\left(\mathrm{CM}_{1}\right)$ which was comparable with treatment puddled direct seeding $\left(\mathrm{CM}_{2}\right)$. However, in case of different weed management practices treatment weed free $\left(\mathrm{WM}_{1}\right)$ recorded significantly higher leaf area index. Transplanting method recorded higher LAI over direct seeding this might be due to increase number of green leaves and more number of shoots per unit area resulting from better nutrition due to reduce growth of weeds the results are confirmed with the findings of Jaiswal and Singh (2001).The relative growth rate was more pronouncedly increased as growth proceeds from 0-30 to 30-60 DAS while it was decreased further during 60-90 DAS regardless the treatments. The lowest relative growth rate $\left(\mathrm{g}_{\text {plant }}{ }^{-1}\right.$ day $\left.{ }^{1}\right)$ was noticed when unpuddled dry direct seeding by line sowing were sown $(0.056$, 0.033 and 0.014 during 0-30, 30-60 and 60-90 DAS, respectively), which was improved with imposing treatments being maximum $(0.065$, 0.038 and $0.017 \mathrm{~g} \mathrm{plant}^{-1}$ day $^{-1}$ ) RGR under treatment transplanting and puddled direct seeding by drum seeding at all the stages of observation, in later period of growth (0-30 and 30-60 DAS) were found statistical comparable to transplanting. The higher plant height, leaf area index with more number of tillers directly contributed to the growth parameters of rice resulted in higher RGR.
Similar finding was reported by (Yadav et al., 2009).

\section{Yield attributes}

The significantly highest number of panicle $\mathrm{m}^{-2}$ was registered under treatment transplanting method of establishment $\left(\mathrm{CM}_{1}\right)$. Further, lowest number of panicle was observed under treatment unpuddled dry direct seeding $\left(\mathrm{CM}_{3}\right)$. The weed management practices treatment weed free $\left(\mathrm{WM}_{1}\right)$ recorded significantly higher number of panicles and it was at par with treatments mechanical weeding $\left(\mathrm{WM}_{3}\right)$ and chemical weeding $\left(\mathrm{WM}_{4}\right)$. Dhanawate (2000) reported that in case of drilled rice the yield attributing characters like number of panicles $\mathrm{m}^{-2}$, length of panicle, filled grains panicle ${ }^{-1}$, weight of filled grains panicle ${ }^{-1}$ and test weight were significantly higher under weed free check and hand weeding twice than the remaining weed control treatments control unweeded. Sinhababu et al., (1992) confirmed that, the unchecked weeds compete with rice plants for light, nutrients and moisture. The maximum panicle length was observed by transplanting methods of 20 days old seedling which was significant in enhancing panicle length followed by puddled direct seeding by drum seeder and similar panicle length found in rest of treatments (Table2). As the panicles increased $\mathrm{m}^{-2}$ the panicle length may be increased as mentioned by Hassan et al., (2015).The significantly highest grain panicle $^{-1}$ was observed under treatment transplanting method of establishment $\left(\mathrm{CM}_{1}\right)$. The higher test weight was registered under treatment transplanting method of establishment $\left(\mathrm{CM}_{1}\right)$ which was at par with treatment puddled direct seeding $\left(\mathrm{CM}_{2}\right)$. The weed management practices treatment weed free $\left(\mathrm{WM}_{1}\right)$ recorded significantly highest test weight and it was at par with treatment mechanical weeding $\left(\mathrm{WM}_{3}\right)$ and chemical weeding $\left(\mathrm{WM}_{4}\right)$. 
Table.1 Plant height, no of tiller of per plant, no of leaves, LAI at harvest and relative growth rate at different intervals as influence by different crop establishment methods and weed management practices under partial irrigated conditions

\begin{tabular}{|c|c|c|c|c|c|c|c|}
\hline \multirow[t]{2}{*}{ Treatment } & \multirow[t]{2}{*}{$\begin{array}{l}\text { Plant height } \\
\text { (cm) at harvest }\end{array}$} & \multirow{2}{*}{$\begin{array}{c}\text { No. of tillers } \\
\text { plant }^{-1} \text { at } \\
\text { harvest }\end{array}$} & \multirow[t]{2}{*}{$\begin{array}{l}\text { No. of leaves at } \\
\text { harvest }\end{array}$} & \multirow[t]{2}{*}{$\begin{array}{l}\text { LAI at } \\
\text { harvest }\end{array}$} & \multicolumn{3}{|c|}{$\begin{array}{c}\text { Relative Growth Rate (RGR) (g } \\
\left.\text { plant }^{-1} \text { day }^{-1}\right)\end{array}$} \\
\hline & & & & & 0-30 DAS & 30-60 DAS & 60-90 DAS \\
\hline \multicolumn{8}{|c|}{$\begin{array}{c}\text { Crop establishment } \\
\text { methods }\end{array}$} \\
\hline $\mathrm{CM}_{1}$ & 90.73 & 9.95 & 37.3 & 4.77 & 0.065 & 0.038 & 0.017 \\
\hline $\mathbf{C M}_{2}$ : & 90.05 & 9.61 & 36.17 & 4.54 & 0.060 & 0.036 & 0.015 \\
\hline $\mathrm{CM}_{3}$ : & 84.99 & 8.20 & 32.86 & 3.67 & 0.056 & 0.033 & 0.014 \\
\hline SEm \pm & 0.44 & 0.10 & 0.11 & 0.03 & 0.001 & 0.001 & 0.001 \\
\hline $\mathrm{CD}(\mathrm{P}=\mathbf{0 . 0 5})$ & 1.78 & 0.42 & 0.45 & 0.14 & 0.004 & 0.002 & NS \\
\hline \multicolumn{8}{|c|}{$\begin{array}{c}\text { Weed management } \\
\text { practices }\end{array}$} \\
\hline $\mathrm{WM}_{1}$ : & 92.37 & 9.68 & 37.45 & 4.67 & 0.063 & 0.039 & 0.019 \\
\hline $\mathbf{W M}_{2}$ & 81.09 & 8.44 & 32.9 & 4.13 & 0.054 & 0.032 & 0.011 \\
\hline $\mathbf{W M}_{3}:$ & 90.29 & 9.30 & 35.95 & 4.11 & 0.061 & 0.035 & 0.016 \\
\hline $\mathrm{WM}_{4}$ : & 90.6 & 9.58 & 35.45 & 4.4 & 0.062 & 0.036 & 0.017 \\
\hline SEm \pm & 0.40 & 0.10 & 0.18 & 0.09 & 0.001 & 0.001 & 0.001 \\
\hline $\mathrm{CD}(\mathrm{P}=\mathbf{0 . 0 5})$ & 1.20 & 0.29 & 0.54 & 0.28 & 0.002 & 0.002 & 0.001 \\
\hline Interaction & $\mathrm{S}$ & $\mathrm{S}$ & $\mathrm{S}$ & $\mathrm{S}$ & NS & NS & NS \\
\hline
\end{tabular}

Main plot: Establishment methods (3): Transplanting (CM1), Puddled direct seeding (drum seeder) (CM2), unpuddled dry direct seeding (CM3)Sub plot: Weed management practices (4): Weed free (WM1), weedy check (WM2), Mechanical weeding (WM3) and chemical weeding (WM4) 
Table.2 No. of panicle $\mathrm{m}^{-2}$,Panicle length (cm),Grains panicle ${ }^{-1}, 1000$ seed weight $(\mathrm{g})$, Grain yield( $\left(\mathrm{q} \mathrm{ha}^{-1}\right)$, straw yield( $\left(\mathrm{q}\right.$ ha $\left.{ }^{-1}\right)$, harvest index, gross return, net return and b:c ratio as influence by deferent crop establishment methods and weed management practices under partial irrigated conditions

\begin{tabular}{|c|c|c|c|c|c|c|c|c|c|c|}
\hline \multirow[t]{2}{*}{ Treatments } & \multicolumn{10}{|c|}{ Yield attributing characters, yield and economics } \\
\hline & $\begin{array}{c}\text { No. of } \\
\text { panicle } \\
\mathbf{m}^{-2}\end{array}$ & $\begin{array}{c}\text { Panicle } \\
\text { length } \\
\text { (cm) }\end{array}$ & $\begin{array}{c}\text { Grains } \\
\text { panicle }^{-1}\end{array}$ & $\begin{array}{c}1000 \\
\text { seed } \\
\text { weigh } \\
t(g)\end{array}$ & $\begin{array}{c}\text { Grain } \\
\text { Yield } \\
\left(\mathbf{q} \mathbf{h a}^{-1}\right)\end{array}$ & $\begin{array}{c}\text { Straw } \\
\text { Yield } \\
\left(\mathbf{q} \mathbf{h a}^{-1}\right)\end{array}$ & $\begin{array}{c}\text { Harves } \\
\text { t Index } \\
(\%)\end{array}$ & $\begin{array}{c}\text { Gross } \\
\text { Return } \\
\left(\square \mathbf{h a}^{-1}\right)\end{array}$ & $\begin{array}{c}\text { Net } \\
\text { return } \\
\left(\begin{array}{c}\square \text { hà } \\
1 \text { ) }\end{array}\right.\end{array}$ & $\begin{array}{c}\text { B:C } \\
\text { Ratio }\end{array}$ \\
\hline \multicolumn{11}{|c|}{ Crop establishment methods } \\
\hline $\mathrm{CM}_{1}:$ & 379.00 & 27.63 & 179.49 & 27.62 & 6243 & 7603 & 45.10 & 131831 & 95411 & 2.61 \\
\hline $\mathrm{CM}_{2}$ : & 352.16 & 26.34 & 177.44 & 26.13 & 5742 & 7906 & 42.14 & 123086 & 87457 & 2.44 \\
\hline $\mathrm{CM}_{3}$ : & 322.41 & 26.98 & 166.62 & 24.34 & 5019 & 7001 & 41.77 & 107757 & 73608 & 2.15 \\
\hline SEm \pm & 4.52 & 0.324 & 0.195 & 0.4 & 83.6 & 128.0 & 0.2 & 1792 & 1792 & 0.05 \\
\hline $\mathrm{CD}(\mathrm{P}=\mathbf{0 . 0 5})$ & 18.24 & NS & 0.786 & 1.6 & 336.0 & 516.1 & 0.7 & 7225 & 7225 & 0.204 \\
\hline \multicolumn{11}{|c|}{ Weed management practices } \\
\hline $\mathrm{WM}_{1}:$ & 368.33 & 27.66 & 175.12 & 26.65 & 6302 & 8164 & 43.60 & 134065 & 97437 & 2.65 \\
\hline $\mathbf{W M}_{2}$ : & 313.66 & 26.57 & 173.54 & 25.29 & 4917 & 6524 & 43.01 & 104909 & 71011 & 2.09 \\
\hline $\mathrm{WM}_{3}:$ & 357.55 & 26.67 & 174.83 & 26.10 & 5784 & 7750 & 42.66 & 123553 & 87198 & 2.39 \\
\hline $\mathrm{WM}_{4}:$ & 365.22 & 27.02 & 174.59 & 26.07 & 5668 & 7574 & 42.76 & 121039 & 86322 & 2.48 \\
\hline SEm \pm & 11.12 & 0.299 & 0.418 & 0.283 & 102.7 & 259.3 & 0.492 & 2390 & 2390 & 0.068 \\
\hline $\mathrm{CD}(\mathrm{P}=\mathbf{0 . 0 5})$ & 33.29 & NS & NS & 0.846 & 307.67 & 776.4 & NS & 7158 & 7158 & 0.203 \\
\hline Interaction & NS & NS & NS & NS & NS & NS & NS & NS & NS & NS \\
\hline
\end{tabular}

Main plot: Establishment methods (3): Transplanting (CM1), Puddled direct seeding (drum seeder) (CM2), unpuddled dry direct seeding (CM3)Sub plot: Weed management practices (4): Weed free (WM1), weedy check (WM2), Mechanical weeding (WM3) and chemical weeding (WM4) 
Table.3 Nutrient uptake by grain and straw as influenced by different establishment methods and weed management practices under partial irrigated conditions

\begin{tabular}{|c|c|c|c|c|c|c|}
\hline \multirow[t]{3}{*}{ Treatment } & \multicolumn{6}{|c|}{ Nutrient uptake (kg ha $\left.{ }^{-1}\right)$} \\
\hline & \multicolumn{2}{|c|}{ N uptake } & \multicolumn{2}{|c|}{ P uptake } & \multicolumn{2}{|c|}{ K uptake } \\
\hline & Grain & straw & Grain & Straw & Grain & Straw \\
\hline \multicolumn{7}{|l|}{ Crop establishment methods } \\
\hline $\mathrm{CM}_{1}$ & 43.73 & 29.27 & 11.13 & 7.58 & 13.79 & 74.70 \\
\hline $\mathrm{CM}_{2}:$ & 43.05 & 27.53 & 10.73 & 7.20 & 13.14 & 73.72 \\
\hline $\mathbf{C M}_{3}:$ & 42.94 & 28.80 & 10.78 & 7.35 & 13.11 & 72.45 \\
\hline SEm \pm & 0.18 & 0.27 & 0.2 & 0.2 & 0.14 & 0.48 \\
\hline $\mathrm{CD}(\mathrm{P}=\mathbf{0 . 0 5})$ & NS & 1.07 & NS & NS & 0.55 & NS \\
\hline \multicolumn{7}{|l|}{ Weed management practices } \\
\hline $\mathbf{W M}_{1}:$ & 44.08 & 28.80 & 11.64 & 7.71 & 14.92 & 75.72 \\
\hline $\mathbf{W M}_{2}$ : & 42.21 & 27.46 & 9.96 & 7.17 & 12.43 & 72.12 \\
\hline $\mathbf{W M}_{3}:$ & 43.12 & 28.69 & 10.91 & 7.27 & 12.86 & 73.15 \\
\hline $\mathbf{W M}_{4}$ : & 43.54 & 29.17 & 11.00 & 7.36 & 13.17 & 73.50 \\
\hline SEm \pm & 0.41 & 0.20 & 0.22 & 0.18 & 0.25 & 0.46 \\
\hline $\mathrm{CD}(\mathrm{P}=\mathbf{0 . 0 5})$ & 1.23 & 0.61 & 0.66 & NS & 0.75 & 1.38 \\
\hline Interaction & NS & $\mathbf{S}$ & NS & NS & NS & NS \\
\hline
\end{tabular}

Main plot: Establishment methods (3): Transplanting (CM1), Puddled direct seeding (drum seeder) (CM2), unpuddled dry direct seeding (CM3)Sub plot: Weed management practices (4): Weed free (WM1), weedy check (WM2), Mechanical weeding (WM3) and chemical weeding (WM4) 
Table.4 Weed population count $\left(\mathrm{m}^{-2}\right)$, weed control efficiency $(\%)$ and weed index (\%) as influencedby different crop establishment methods and weed management practices under partial irrigated conditions

\begin{tabular}{|c|c|c|c|c|c|c|c|}
\hline \multirow[t]{2}{*}{ Treatments } & \multicolumn{3}{|c|}{ Weed population count $\left(\mathbf{m}^{-2}\right)$} & \multicolumn{3}{|c|}{ Weed control efficiency $(\%)$} & \multirow[t]{2}{*}{ Weed index $(\%)$} \\
\hline & Grasses & Sedges & BLW & Grasses & Sedges & BLW & \\
\hline \multicolumn{8}{|c|}{ Crop establishment methods } \\
\hline $\mathrm{CM}_{1}:$ & $2.56(7.33)$ & $2.49(6.25)$ & $2.66(7.66)$ & 61.94 & 54.16 & 57.89 & 10.47 \\
\hline $\mathbf{C M}_{2}$ : & $2.78(8.58)$ & $2.84(8.58)$ & $2.86(8.91)$ & 59.44 & 51.28 & 54.92 & 10.66 \\
\hline $\mathbf{C M}_{3}:$ & $3.59(15.25)$ & $3.38(12.75)$ & $3.26(12.00)$ & 58.23 & 50.42 & 54.71 & 11.20 \\
\hline SEm \pm & 0.75 & 0.66 & 0.94 & 1.29 & 1.85 & 3.08 & 3.11 \\
\hline $\mathrm{CD}(\mathrm{P}=\mathbf{0 . 0 5})$ & 3.03 & 2.65 & NS & NS & $\mathrm{NS}$ & NS & NS \\
\hline \multicolumn{8}{|c|}{ Weed management practices } \\
\hline $\mathrm{WM}_{1}:$ & $1.00(0.00)$ & $1.00(0.00)$ & $1.00(0.00)$ & 100.00 & 100.00 & 100.00 & 0.00 \\
\hline $\mathbf{W M}_{2}$ : & $5.10(25.88)$ & $4.45(19.22)$ & $4.74(21.77)$ & 0.00 & 0.00 & 0.00 & 20.17 \\
\hline $\mathbf{W M}_{3}:$ & $3.14(9.11)$ & $3.24(9.77)$ & $3.14(9.00)$ & 63.76 & 48.46 & 57.31 & 13.43 \\
\hline $\mathbf{W M}_{4}:$ & $2.67(6.55)$ & $2.92(7.77)$ & $2.84(7.33)$ & 75.75 & 59.37 & 66.05 & 9.50 \\
\hline SEm \pm & 0.98 & 0.71 & 0.83 & 1.50 & 2.48 & 2.22 & 1.75 \\
\hline $\mathrm{CD}(\mathrm{P}=\mathbf{0 . 0 5})$ & 2.93 & 2.12 & 2.48 & 4.49 & 7.43 & 6.63 & 5.23 \\
\hline Interaction & $\mathrm{S}$ & S & $\mathrm{S}$ & & & & \\
\hline
\end{tabular}

Original values are given in Parentheses. BLW - Broad leaved weeds, Main plot: Establishment methods (3): Transplanting (CM1), Puddled direct seeding (drum seeder) (CM2), unpuddled dry direct seeding (CM3)Sub plot: Weed management practices (4): Weed free (WM1), weedy check (WM2), Mechanical weeding (WM3) and chemical weeding (WM4) 
Significant increase in the number of panicle $\mathrm{m}^{-2}$, grain panicle ${ }^{-1}$, panicle weight, panicle length and 1000 grain weight under treatment transplanting method of establishment. The significantly highest grain yield was registered under treatment transplanting method of establishment $\left(\mathrm{CM}_{1}\right)$ over rest of the establishment methods. The weed management practices treatment weed free $\left(W_{1}\right)$ registered significantly higher grain yield. Kim and Pyon (1998) who reported that uncontrolled weeds reduced the yield by $96 \%$ in dry direct seeded rice, $61 \%$ in wet seeded rice and $40 \%$ in transplanted rice. Transplanting method and drum seeding recorded significantly higher paddy yield because desired planting distance confirms air movement, water and light which are basic factors needed for photosynthesis. Further, proper spacing increases tiller and yield.

The significantly highest straw yield was observed under establishment methods puddled direct seeding $\left(\mathrm{CM}_{2}\right)$ which was at par with treatment transplanting method of establishment $\left(\mathrm{CM}_{1}\right)$.

The weed management practices treatment weed free $\left(\mathrm{WM}_{1}\right)$ registered significantly highest straw yield which was at par with treatment mechanical weeding $\left(\mathrm{WM}_{3}\right)$ and chemical weeding $\left(\mathrm{WM}_{4}\right)$. Further, the lowest straw yield was registered under treatment weedy check $\left(\mathrm{WM}_{2}\right)$. Significantly highest harvest index under treatment transplanting method of establishment $\left(\mathrm{CM}_{1}\right)$ over rest of the establishment methods. Moreover, the lowest harvest index was observed under treatment unpuddled dry direct seeding $\left(\mathrm{CM}_{3}\right)$.

\section{$\mathrm{N}, \mathrm{P}$ and $\mathrm{K}$ uptake in grain and straw of rice}

The $\mathrm{N}$ uptake in grain was found statistically non-significant for different crop establishment methods. However, in case of different weed management practices significantly highest $\mathrm{N}$ uptake in grain was observed under treatment weed free $\left(\mathrm{WM}_{1}\right)$ which was at par with treatments mechanical weeding $\left(\mathrm{WM}_{3}\right)$ and chemical weeding $\left(\mathrm{WM}_{4}\right)$. while, the lowest $\mathrm{N}$ uptake in grain was observed under treatment weedy check $\left(\mathrm{WM}_{2}\right)$. The significantly highest $\mathrm{N}$ uptake in straw was recorded under treatment transplanting method of establishment $\left(\mathrm{CM}_{1}\right)$ which was at par with treatment unpuddled dry direct seeding $\left(\mathrm{CM}_{3}\right)$. Further, in case of different weed management practices treatment chemical weeding $\left(\mathrm{WM}_{4}\right)$ observed significantly highest $\mathrm{N}$ uptake in straw and it was at par with treatment weed free $\left(\mathrm{WM}_{1}\right)$ and mechanical weeding $\left(\mathrm{WM}_{3}\right)$. However, the lowest $\mathrm{N}$ uptake in straw was noticed under treatment weedy check $\left(\mathrm{WM}_{2}\right)$. The $\mathrm{P}$ uptake in grain was found statistically nonsignificant for different crop establishment methods. Further, in case of different weed management practices treatment weed free $\left(W_{1}\right)$ observed significantly highest $P$ uptake in grain and it was at par with treatment chemical weeding $\left(\mathrm{WM}_{4}\right)$ while, the lowest $\mathrm{P}$ uptake in grain was observed under treatment weedy check $\left(\mathrm{WM}_{2}\right)$. The interaction effect was found non-significant for $\mathrm{P}$ content in grain. The $\mathrm{P}$ uptake in straw, different weed management practices and interaction effect was found non-significant for $\mathrm{P}$ uptake in straw. More phosphorus uptake by rice under transplanted establishment method might be due to greater phosphorus availability and more grain and straw yield. The higher uptake of potassium in transplanted method might be due to higher nutrient concentration under puddled conditions by the formation of slurry type of structure which restricted water and nutrient losses to the lower depth and provided better opportunity for diffusion and uptake of nutrients and proliferation of roots with in the deep puddled layer. The significantly highest 
$\mathrm{K}$ uptake in grain was registered under treatment transplanting method of establishment $\left(\mathrm{CM}_{1}\right)$. Further, the lowest $\mathrm{K}$ uptake in grain was observed under treatment unpuddled dry direct seeding $\left(\mathrm{CM}_{3}\right)$. However, in case of different weed management practices treatment weed free $\left(\mathrm{WM}_{1}\right)$ observed significantly highest $\mathrm{K}$ uptake in grain while, the lowest $\mathrm{K}$ uptake in grain was observed under treatment weedy check $\left(\mathrm{WM}_{2}\right)$. The $\mathrm{K}$ uptake in straw was found statistically non-significant for different crop establishment methods. The weed management practices treatment weed free $\left(W_{1}\right)$ observed significantly highest $\mathrm{K}$ uptake in straw. Further, the lowest K uptake in straw was recorded under treatment weedy check $\left(\mathrm{MW}_{2}\right) . \quad$ Maximum nitrogen, phosphorus and potassium uptake by grain (56.6, 11.1 and $22.92 \mathrm{~kg} \mathrm{ha}^{-1}$, respectively) and straw (36.6, 2.63 and $41.34 \mathrm{~kg} \mathrm{ha}^{-1}$, respectively) and their total uptake $(106.8 \mathrm{~kg}$ $\mathrm{ha}^{-1}, 14.6 \mathrm{~kg} \mathrm{ha}{ }^{-1}$ and $120.3 \mathrm{~kg} \mathrm{ha}^{-1}$, respectively) were found in transplanted rice.

\section{Economics}

The data revealed that the transplanting method of establishment $\left(\mathrm{CM}_{1}\right)$ was recorded significantly higher gross return. Moreover, lowest gross return was registered under treatment unpuddled dry direct seeding $\left(\mathrm{CM}_{3}\right)$. However, in case of different weed management practices treatment weed free $\left(\mathrm{WM}_{1}\right)$ was noticed higher gross return and lowest gross return was observed under treatment weedy check $\left(\mathrm{WM}_{2}\right)$.The significantly higher net return was registered under transplanting method of establishment $\left(\mathrm{CM}_{1}\right)$. Further, lowest net return was registered under treatment unpuddled dry direct seeding $\left(\mathrm{CM}_{3}\right)$. However, in case of different weed management practices treatment weed free $\left(\mathrm{WM}_{1}\right)$ recorded highest net return. However, lowest net return was observed under treatment weedy check
$\left(\mathrm{WM}_{2}\right)$.The significantly higher B: C ratio was registered under treatment transplanting method of establishment $\left(\mathrm{CM}_{1}\right)$ which was at par with treatment puddled direct seeding $\left(\mathrm{CM}_{2}\right)$. Moreover, lowest B: C ratio was observed under treatment unpuddled dry direct seeding $\left(\mathrm{CM}_{3}\right)$. However, in case of different weed management practices treatment weed free $\left(\mathrm{WM}_{1}\right)$ noticed highest $\mathrm{B}$ : $\mathrm{C}$ ratio and it was at par with treatment chemical weeding $\left(\mathrm{WM}_{4}\right)$. Further, lowest B: $\mathrm{C}$ ratio was observed under treatment weedy check $\left(\mathrm{WM}_{2}\right)$. Similar result was obtained by Thakur (1993). The reason might be that puddled transplanting provided better environment condition accelerated the growth of the plant which resulted increased crop yield.

\section{Weeds studies}

The significantly lower population of grasses was observed under treatment transplanting method of establishment $\left(\mathrm{CM}_{1}\right)$. Further, the highest population of grasses, sedges and broad leaved weeds was recorded under treatment unpuddled dry direct seeding $\left(\mathrm{CM}_{3}\right)$.

However, in case of different weed management practices treatment weed free $\left(\mathrm{WM}_{1}\right)$ recorded significantly lowest population of grasses as compared to chemical weeding $\left(\mathrm{WM}_{4}\right)$. Further, the highest population of grasses was observed under treatment weedy check $\left(\mathrm{WM}_{2}\right)$. Transplanted and wet seeded rice resulted in lower density and dry matter of individual weeds mainly because of puddling which gave lesser emergence of deeply placed weed seeds. Sowing of sprouted seeds through drum seeder under puddled condition (WSR) also proved superior over DSR with respect to control of total weeds. The highest density of total weeds was observed under DSR. The results are in agreement with the findings of 
Singh et al., (2005). The weed management practices the highest weed control efficiency was registered under treatment weed free $\left(W_{1}\right)$ at all the stages of observation. Further, the lowest weed control efficiency of grasses, sedges and broad leaved weeds was registered under treatment weedy check $\left(\mathrm{WM}_{2}\right)$. The significantly highest weed control efficiency of sedges were noticed under treatment transplanting method of establishment $\left(\mathrm{CM}_{1}\right)$. Further, the lowest weed control efficiency was registered under treatment unpuddled dry direct seeding $\left(\mathrm{CM}_{3}\right)$. However, in case of different weed management practices significantly highest weed control efficiency of grasses, sedges and BLW were noticed under treatment weed free $\left(\mathrm{WM}_{1}\right)$. While the lowest weed control efficiency of grasses, sedges and BLW was recorded under treatment weedy check $\left(\mathrm{WM}_{2}\right)$. The crop establishment methods was found statistically non-significant for weed control efficiency. Hassan et al., (2014) reported the impact of establishment is also reflected in terms of weed control efficiency as transplanted rice registered higher (71.18\%) weed control efficiency compared to SRI drum seeded and broadcasted rice. Deshmukh et al., (1987) noted that herbicides with one hand weeding resulted in lower weed density, dry weight and gave higher weed control efficiency compared to chemical weeding alone and untreated control. The methods of establishment was found statistically non-significant for weed index. Further, in case of different weed management practices treatment weedy check $\left(W_{2}\right)$ observed significantly highest weed index was noticed and the lowest weed index was recorded under treatment weed free $\left(\mathrm{WM}_{2}\right)$. Balasubhramanian and Hill. (2002) observed that the two hand weeding at 20 and 40 DAT recorded minimum weed count $\mathrm{m}^{-2}$ (2.06 and 4.14), dry weight of weeds, weed index (6.30 and 5.57\%) and maximum weed control efficiency (93.6 and 96.4\%) under transplanted rice as compared to unweeded check during both the years.

In conclusions the treatment transplanted method of establishment of rice gave higher dry matter accumulation, leaf area index, root volume, root dry weight, yield attributes and yield followed by puddled direct seeded by drum seeder method of establishment. Further, for weed management practices above characters were found under treatment weed free followed by chemical weeding. The gross income was numerically highest under treatment transplanting method of establishment. Further, net return and B: C ratio was higher under treatment transplanted method of establishment followed by puddled direct seeding by drum seeder method.

\section{References}

Ali, Q.M., Ahmad, A., Ahmed, M., Arain, M.A. and Abbas, M. 2013. Evaluation of planting methods for growth and yield of paddy (Oryzasativa L.) under agro-ecological conditions of district Shikarpur. American-Eurasian Journal of Agricultural and Environmental Sciences, 13(11): 1503-1508.

Anonymous. 2019. KrishiDarshika, Annual publication of Directorate of Extension Services, IGKV, Raipur (C.G.).

Balasubramanian, P. and Palaniappan, S. P. 2001. Principles and practices of Agronomy. Agrobios Publishing co. Pvt. Ltd., New Delhi: 306-364

Balasubramanian, V. and Hill, J. E. 2002. Direct seeding of rice in Asia: emerging issues and strategic research needs for $21^{\text {st }}$ century. pp. 15-42. In: Direct seeding: Research Strategies and Opportunity. (Eds. Pandey S, Mortimer M, Wade L, Tuong TP, Lopez $\mathrm{K}$ and Hardy B), International Rice Research Institute, Los banos, Phillippines.

Barik, A. K., Das, A., Giri, A. K. and 
Chattopadhyay, G. N. 2006. Effect of integrated plant nutrient management on growth, yield and production economics of wet season rice (Oryza sativa). Indian J. of Agric. Sci. 76(11):657-60.

Deshmukh, M. R., Trivedi, K. K. and Tiwari, J. P. 1987. Response of upland rice to weed control methods. IRRN: 12(4): 47.

Dhanawate V.B. 2000. Effect of row spacing and herbicides on the growth and yield of direct seeded rice. M. Sc. (Agri.) thesis (unpublished), Dr. Balasaheb Sawant Konkan Krishi Vidyapeeth, Dapoli, India.

Farooq, M., Siddique, K.H.M., Rehman, H., Aziz, T., Lee, D.J. and Wahid, A. 2011. Rice direct seeding: Expeiences, challenges and oppurtunities. Soil and Tillage Research, 111: 87-98.

Hassan, D. and Upasani, R. R. 2014. Effect of crop establishment and weed control methods on productivity of rice (Oryza sativa L.) Indian J. Agron.

Hassan, D. and Upasani, R.R. 2015. Effect of crop establishment and weed control methods on productivity of rice (Oryza sativa L.). Journal crop and weed, 11: 228-230.

Ho and Romil, 2000. Impact of direct seeding of rice cultivation: lessen from the Mudaaraof Malaysia. In: Direct seeding: Research strategies and opportunities Eds: Proceedings of International Workshop on direct seeding in Asia Rice System, held during 25-28 January, Bangkok,
Thailand.

Hugar, A.Y., Chandrappa, H., Jayadev, H.M., Sathish, A. and Mallikarjun, B. 2009. Influence of different establishment methods on yield and economics of rice. Agricultural Science Digest, 29: $202-$ 205.

Jaiswal, V. P., and Singh, G.R. 2001. Effect of planting methods, source and level of nitrogen on the growth and yield of rice (Oryza sativa) and on succeeding wheat (Triticum aestivum). Indian Journal of Agronomy.; 46(1):5-11.

Kim, H.H. and Pyon, J. Y., 1998. Weed occurrence and yield loss due to weeds in different seeded rice paddy fields. Korean J. weed Sci., 18 (1): 12-19.

Singh, A., Anbumani, R.P. and Singh, R. D. 1997. Performance of rice (Oryza sativa) under different methods of cultivation in hilly soils of Sikkim Indian J of Agron. 42 (4): 611-613.

Sinhababu, D. P., Moorthy, B.T.S., Rajamani, S. and Mann, G.B. 1992. Integrated weed management benefits direct seeded upland rice. Indian Fmg. 42: 7-8.

Thakur, R. B. 1993. Effect of sowing methods and seed rate on the performance of high yielding varieties of rice. Indian J. Agron., 38 (4): 547-550.

Yadav, D. B., Yadav, A. and Punia, S.S. 2009. Evaluation of Bispyribac- sodium for weed control in transplanted rice. Indian Journal of Weed Science, 41(12): 23-27.

\section{How to cite this article:}

Khilendra Kumar Sahu, M. Kumar, A. Pradhan, T. Chandrakar and Singh, D. P. 2021. Yield and Weed Dynamics as Influenced by Different Rice Establishment Methods under Partial Irrigated Condition. Int.J.Curr.Microbiol.App.Sci. 10(01): 2981-2992. doi: https://doi.org/10.20546/ijcmas.2021.1001.345 